Zavoda za znanstveni rad

HAZU Varaždin

SLOBODAN KAŠTELA,

član suradnik Hrvatske akademije

slobodan@hazu.hr
Primljeno: 29. 10. 2018.

Prihvaćeno: 30. 10. 2018.

DOI: https://dx.doi.org/10.21857/mnlqgc06oy

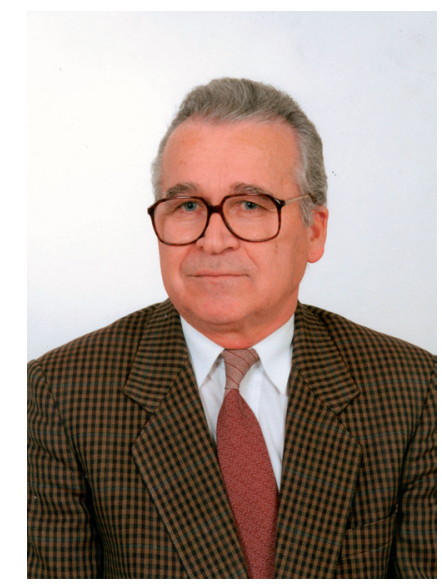

\title{
IN MEMORIAM: \\ PROFESSOR EMERITUS FRANJO RUŽA (1931. - 2017.)
}

U Varaždinu je u 87. godini života umro professor emeritus Franjo Ruža.

Rođen je 26. listopada 1931. u Svetom Roku (danas Novo Selo Rok). Nižu gimnaziju završio je u Čakovcu, gdje je položio i srednjoškolsku maturu u Ekonomskoj školi. Na Ekonomskom fakultetu u Zagrebu diplomirao je 1958. godine. Na istom je fakultetu doktorirao 1973. obranom doktorske disertacije Utjecaj privređivanja na rezultate i uspješnost poslovanja poduzeća konzervne industrije središnje Hrvatske. Od 1962. do umirovljenja 2002., punih četrdeset godina, radio je kao visokoškolski nastavnik, najprije na Višoj ekonomskoj školi u Varaždinu, a zatim od 1974. na Fakultetu organizacije i informatike Varaždin. Za izvanrednog profesora izabran je 1974. godine, za redovitog profesora 1980., a u trajno zvanje redovitog profesora 1999. godine. Odlukom Senata Sveučilišta u Zagrebu 2005. izabran je u počasno zvanje professor emeritus zbog posebnih zasluga za napredak i razvitak Sveučilišta u Zagrebu te međunarodno priznatu nastavnu i znanstvenu izvrsnost. 
Tijekom dugogodišnjeg pedagoškog rada obavljao je više raznih dužnosti. Bio je direktor Više ekonomske škole Varaždin te je intenzivno radio na prerastanju te škole u Fakultet organizacije i informatike Varaždin 1974. godine. Iste godine izabran je za prvog dekana Fakulteta i u to je vrijeme bio među najmlađim dekanima Sveučilišta u Zagrebu. Na tu je dužnost ponovno biran još u dva mandata. Bio je inicijator osnivanja poslijediplomskog studija 1981. godine te je bio njegov voditelj pet godina.

Franjo Ruža bio je voditelj i organizator brojnih znanstvenih skupova i savjetovanja, od kojih je jedan od najznačajnijih posvećen obilježavanju 800. godišnjice prvog spomena grada Varaždina. Skup koji se pripremao pune tri godine organizirali su tadašnja Jugoslavenska, danas Hrvatska, akademija znanosti i umjetnosti i Grad Varaždin. Rezultat tog trodnevnog skupa (s više od sedamdeset izlaganja) bilo je opsežno djelo Varaždinski zbornik 1181. - 1981., koje se s pravom naziva enciklopedijom Varaždina. I ne samo to. Zahvaljujući toj suradnji s Akademijom, ubrzo je osnovan i Zavod za znanstveni rad u Varaždinu. Temeljni zadatak novoosnovanog Akademijina zavoda bio je da postane nosilac znanstvenoistraživačkog rada ponajprije na području grada Varaždina, ali i na širem području sjeverozapadne Hrvatske (Čakovec, Koprivnica, Ivanec, Ludbreg, Varaždinske Toplice). Odlukom Predsjedništva Akademije za voditelja Zavoda imenovan je akademik Andre Mohorovičić, a za upravitelja profesor Franjo Ruža, koji je na toj dužnosti ostao punih deset godina, kada je, zbog bolesti, morao napustiti taj posao, koji je izvanredno uspješno obavljao. I nakon toga gotovo do smrti profesor Ruža ostao je uvaženi član Znanstvenog vijeća Zavoda.

Svojim svestranim radom profesor Ruža djelovao je na nizu znanstvenih i kulturnih projekata, među kojima treba istaknuti njegovu suradnju na glazbenom festivalu Varaždinske barokne večeri. Pet je godina bio predsjednik Organizacijskog odbora tog festivala, a još deset godina ostao je član Odbora.

Kao profesor i dekan Fakulteta bio je neumorni pokretač izdavanja knjiga i časopisa, među kojima posebno spominjemo Zbornik radova Fakulteta organizacije i informatike Varaždin, koji izlazi i danas. U funkciji upravitelja Zavoda za znanstveni rad u Varaždinu pokrenuo je, uz svesrdnu podršku akademika Andre Mohorovičića, časopis Radovi, koji redovito izlazi i danas. Uz taj znanstveni časopis, u njegovo vrijeme pokrenuta je i edicija Posebna izdanja Zavoda za znanstveni rad $u$ Varaždinu u okviru koje je objavljeno ukupno 27 knjiga.

Osim spomenutog, u Zavodu su se pripremala i tiskala brojna važna djela hrvatske kulture i znanosti kao što su pretisci djela Antuna Vramca - Postila i Kronika. Ta su vrijedna djela tiskana u 16. stoljeću i spadaju među prva djela napisana na kajkavskom književnom jeziku. Dakako, najvažniji projekt varaždinskog Zavoda na kojem je od samog početka sudjelovao Franjo Ruža bio je projekt 
Stvaralački potencijali u funkciji društvenog razvoja sjeverozapadne Hrvatske, koji je financiralo Ministarstvo znanosti, obrazovanja i športa. Na projektu se radilo punih 11 godina, a rezultati znanstvenih istraživanja predstavljeni su na velikom znanstvenom skupu održanom 2002. godine.

Objavio je brojne radove tiskane u znanstvenim i stručnim časopisima. Kulminacija njegova znanstvenog i pedagoškog rada svakako je sveučilišni udžbenik Ekonomika poduzeća iz 2002., koji je pripremio te bio urednikom i autorom oko polovice tekstova. Za istaknuti znanstveni, stručni i društveni rad Franjo Ruža primio je brojne nagrade i društvena priznanja od kojih ističemo: Nagradu 8. svibnja Općine Varaždin 1976., Priznanje zaslužnom profesoru Sveučilišta u Zagrebu 1989., Spomenicu domovinske zahvalnosti odlukom predsjednika Republike 1997.; Red hrvatskog pletera odlukom predsjednika Republike 1998., Nagradu za životno djelo Grada Varaždina 1998.; Medalju Varaždinskih baroknih večeri 1995. godine.

Profesora Franju Ružu upoznao sam davne 1978. godine, neposredno nakon svog izbora za tajnika Akademije, s obzirom na to da smo tada, zajedno s akademikom Androm Mohorovičićem, radili na pripremi znanstvenog skupa u povodu obilježavanja 800. godišnjice osnutka grada Varaždina. Nakon održanog skupa 1981. te osnivanja Akademijine znanstvene jedinice u Varaždinu 1983. godine, za čijeg je prvog upravitelja bio imenovan Franjo Ruža, naši su kontakti bili gotovo svakodnevni više od desetak godina sve do njegova razrješenja 1993. godine. Međutim, ni nakon toga naša dobra suradnja i prijateljstvo nisu prestali sve do njegove smrti, koja je nastupila točno godinu dana prije pisanja ovoga teksta.

Tijekom tog dugog vremenskog razdoblja profesora Ružu upoznao sam kao izuzetno dragu osobu, skromnog i nenametljivog čovjeka koji je sve svoje vrijeme posvećivao prvenstveno pedagoškom, znanstvenom i društvenom radu. Bio je strpljiv i tolerantan u odnosu na druga mišljenja, posebno onda kada se radilo o donošenju važnih odluka kao što su bili osnivanje visokoškolskih i znanstvenih institucija od značenja za Grad Varaždin i njegovu širu regiju. S tim u vezi teško je i pretpostaviti da bi bez njegova ugleda i autoriteta koji je imao u varaždinskoj sredini moglo doći do osnivanja Fakulteta organizacije i informatike, a podjednako tako i Akademijina Zavoda u Varaždinu.

Povremena druženja s njim i njegovim suradnicima bilo u Varaždinu ili izvan njega uvijek su se odvijala u ugodnoj atmosferi i prijateljskom okruženju, posebno dok je u njima sudjelovao i akademik Andre Mohorovičić, voditelj Zavoda i veliki prijatelj grada Varaždina. Sastavni dio tih susreta bio je razgovor o budućim aktivnostima Zavoda kako bi u što većoj mjeri opravdao ulogu promicatelja znanstvenoistraživačkog rada na širem području Varaždina. 
Premda je najveći dio svog plodnog života Franjo Ruža proveo u Varaždinu, nije zaboravio svoje međimursko porijeklo, a posebnu ljubav i pažnju posvećivao je svojoj obitelji, supruzi Dragici, kćeri Dadi i sinu Darku.

Takav prijatelj i suradnik, veliki i zaslužni čovjek Franjo Ruža ostat će nam u trajnoj uspomeni. 